\title{
Nukleáris baleset-elhárítás Magyarországon, különös tekintettel az egészségügyi hatásokra - I. rész
}

\author{
Nuclear Accident Prevention and Protection in Hungary, \\ with Special Regard to Health Impacts - Part 1
}

A magyarországi nukleáris intézmények biztonsága olyan elsődleges irányelvek kidolgozását tette szükségessé, amelyek minden lehetséges módon, megalapozott védelmifunkciókat valósítanak meg. Az ehhez szükséges szempontokat a meglévő nukleáris technológiai és felhasználási tapasztalatok, az egészségügyi hatástanulmányok és a környzetre gyakorolt hatások alapozzák meg. Az intézményi sajátosságok, mint például a Paksi Atomerőmü baleset-elhárítási rendszerének kidolgozottsága biztositják a széles körü nukleáris baleset-elháritás hatékony alkalmazását, a szükségesség mértékének megfelelően. A két részből álló cikksorozatban a szerzők a magyarországi nukleáris baleset-elháritás eljárásrendjeinek aspektusaira térnek ki, a hozzá tartozó sugárzási és egészségügyi hatásokértékelésével.

Kulcsszavak: atomerömü, reaktor, nukleáris létesítmény, biztonság

In Hungary the safety requirements of nuclear facilities have made it necessary to elaborate such primary principles that accomplish well-established, comprehensive protective functions.

The elaboration criteria are based on the existing experiences of nuclear technologies and their applications, the findings of health and environmental impact studies. The specificities of the individual facilities, such as the detailed elaboration of the accident prevention and protection system of the nuclear power plant in Paks, assure the effective implementation of the comprehensive nuclear accident protection, in accordance with the necessities.

1 MVM Paksi Atomerőmű Zrt., Atomix Kft. Létesítményi Tüzoltóság, szerparancsnok, e-mail: antalzmax@gmail.com, ORCID: 0000-0001-9373-3454

2 Belügyminisztérium, Nemzeti Közszolgálati Egyetem Katonai Müszaki Doktori Iskola oktatója, helyettes rendvédelmi tiszti föorvos, e-mail: robertrevai@gmail.com, ORCID: 0000-0001-7282-6555

3 Országos Katasztrófavédelmi Főigazgatóság, országos tűzoltósági főfelügyelő, tű. dandártábornok, e-mail: laszlo. berczi@katved.gov.hu, ORCID: 0000-0001-7719-7671 
In the two parts of the present article the authors cover the aspects of the policies and procedures of Hungarian nuclear accident protection, with the assessment of related radiation and health impacts.

Keywords: nuclear power plant/station, reactor, nuclear facility, safety

\section{Bevezetés}

A magyarországi nukleárisbaleset-elhárítás több szinten, rétegezve épül fel, megfelelve az európai uniós követelményeknek és az országon belüli nukleáris sajátosságoknak, valamint igazodik a környező országok nukleáris programjaihoz és baleset-elhárítási protokollokat valósít meg. A Paksi Atomerőmüben külön speciális baleset-elhárítási szervezet és rendszer müködik, amely kiépítettségében és alkalmazott megoldásaival egyedülálló a maga nemében. Az országos rendszerekhez kapcsolódva, azokkal összhangban müködik, a komplex nukleárisbaleset-elhárítás körében és a katasztrófavédelem hathatós közremüködésével. ${ }^{4}$

A hazai nukleárisbaleset-elhárítás tekintetében négy fontos létesítményt kell megemlítenünk. Elsőként a Paksi Atomerőművet, amely a magyarországi villamosenergia-termelésének legjelentősebb forrása, hiszen a villamos energia több mint 50\%-a innen származik. Az erőmű négy VVER 440/213 típusú vízhütéses - vízmoderátoros reaktorblokkot üzemeltet, a hozzájuk tartozó, a nukleáris biztonságot széles körben lefedő emberi, technológiai és infrastrukturális háttérrel. A környező országok atomerőműi is fontos szerepet játszanak, és hozzá tartoznak a magyarországi nukleárisbaleset-elhárítás tervezéséhez és rendszeréhez. Másodikként fontos, a Paksi Atomerőmüben keletkezett elhasznált fütőelemek hosszú távú tárolására és hűtésére szolgáló Kiégett Kazetták Átmeneti Tárolója, amely az atomerőmű közvetlen szomszédságában üzemel. A KFKI Atomenergia Kutatóintézetben müködik továbbá a Budapesti Kutatóreaktor, amelynek reaktora fizikai és nukleáris technológiai kutatásokhoz szolgál nagy teljesítményű neutronforrásként és kutatási felhasználásra állít elő radioizotópot. Végül a Budapesti Műszaki és Gazdaságtudományi Egyetem oktatóreaktora a felsőoktatási intézmények hallgatóinak képzésében játszik fontos szerepet, hogy a reaktorhoz kapcsolódó laboratóriumi és reaktorüzemeltetési ismeretek gyakorlati alkalmazását valósítsa meg. ${ }^{5}$

A radioaktív anyagokat tároló létesítmények ugyan nem rendelkeznek müködő atomreaktorral, azonban nukleárisbaleset-elhárítás szempontjából mégis releváns fenyegetést jelenthetnek, így e létesítmények is részei a védelmi tervezésnek. A Nemzeti Radioaktívhulladék-tároló Bátaapátiban található, ahol az atomerőmüben keletkező kis és közepes aktivitású szilárd vagy folyékony hulladékok tárolását valósítják meg. A végleges elhelyezésre csak szilárd formában kerülhet sor, ezért a folyékony hulladékokat speciális eljárásokkal szilárdítják meg az atomerőmüben, mielőtt ideszállítják. A Püspökszilágyi Radioaktív Hulladék Feldolgozó és Tároló feladata, hogy az olyan kis és közepes aktivitású hulladékok elhelyezését megvalósítsa, amely nem az atomerőmüben keletkezett.

1996. évi CXVI. törvény; ÁVIT 2016, I. modul.

BOGNÁr et al. 2013. 
A veszélyelhárítást az alapvető fogalmak és rendszerek bemutatásával, azok összefüggéseinek és müködési sémáik taglalásával kell hogy ismertessük, hiszen minden egyes országos vagy lokális intézkedéseket és besorolásokat jelentő szint szervesen kapcsolódik egymáshoz.

\section{Nukleáris veszélyeztetettség}

A nukleáris veszélyhelyzetek forrása lehet maga a nukleáris létesítmény vagy olyan radiológiai káresemény, amely emberi hibából vagy szándékosságból ered. Az ellenőrizetlenül hagyott, ellopott, elvesztett, helytelenül használt vagy szállított, talált radioaktív anyagok, egészségügyi sugárforrások továbbá veszélyes ipari röntgenforrások okozhatnak olyan baleseteket, amelyeket nukleáris balesetként kell kezelnünk. A potenciális veszélyhelyzet megfelelő értékeléséhez mindenekelőtt a veszélyforrás sajátosságait kell fókuszba helyeznünk.

\section{lonizáló sugárzás}

A nukleáris veszélyhelyzetek olyan rendkívüli eseményeket foglalnak magukban, amelyeknél a lakosság védelmében ionizáló sugárzás okozta veszélyhelyzet elhárítására vagy a következmények enyhítésére irányuló intézkedésekre van szükség. Más hatásokkal ellentétben, mint például rezgések, elektromos áram, hő, az ionizáló sugárzás nem kelt közvetlen érzetet, általános módon érzékszerveinkkel nem érzékelhető, mégis egészségkárosító hatása lehet. Az ionizáló sugárzás elleni alapvető védelem négy elemből épül fel, ezek az idő, a távolság és az árnyékolás védőhatásai, amelyekhez az emberi szervezet, mint káros hatásokat felfogó rendszer kapcsolódik, lényegében a sugár fajtája és az egyes emberi szövetek specifikussága befolyásolja a káros hatásokat.

A sugárzás mértéke számokban kifejezve több módon lehetséges. Az anyagokban elnyelődött sugárzás meghatározható mennyiségét, azaz dózisát a "Gray" mértékegység (Gy) jelöli, míg a biológiai szövetekben elnyelődött sugárzási adagot egy ezzel megegyező dimenziójú mértékegység, a „Sievert” (Sv) fejezi ki. A mértékegységek megfelelnek 1 kg szövet által elnyelt 1 J sugárzási energiának ( $\mathrm{Gy}=\mathrm{J} / \mathrm{kg}$ ), ugyanakkor a különböző sugárzások energiatartománya változó, ebböl következik, hogy a sugárzás típusa és energiatartománya alapján módosul a dózis mértéke. Az emberi szervek és szövetek által elnyelt dózis azok specifikusságának függvényében védenek, illetve tovább súlyosbítanak a sugárzás mértékén. Látható tehát, hogy a sugárzás, mint gyűjtőfogalom olyan többkomponensű veszélyeztető hatás, amelynek nemcsak a detektálása, de a hatásai is széles spektrumon mozognak. Éppen ezért a nukleárisbaleset-elhárítás elsődleges célja, hogy a lakosságot minden lehetséges módon védje a baleset következtében kiszabaduló sugárterheléstöl. ${ }^{6}$

6 BEREK 2010; 487/2015. Korm. rendelet. 


\section{Sugárzás fajtája és hatásai}

Alfa-sugárzás: Kis áthatoló képességü sugárzás, amely könnyen elnyelődik, akár egy vékony papírlapban vagy az emberi bőr felületén. Veszélyességét, a lenyelt vagy belélegzett $\alpha$-sugárzó hatásai adják, mivel közvetlenül az élő sejteket bombázva súlyos elváltozásokat és rákosodást okoz.

Béta-sugárzás: Nagyobb áthatoló-képességgel bír ugyan, mint az $\alpha$-sugár, de a külső dózishoz csak kis mértékben járul hozzá. Néhány centiméter után elnyelődik a levegőben, de vékony fán, müanyagon vagy alumíniumlemezen már nem tud áthatolni. A szervezetbe kerülve azonban komoly károsodást okoz. A szervezetben feldúsulva a környező szöveteket nagymértékben roncsolja.

Gamma-sugárzás: A $\gamma$-sugárzás jellemzője, hogy nagy áthatoló-képességgel rendelkező elektromágneses sugárzás, mivel nincs tömege és nincs töltése. Árnyékolásra van szükség, hogy védekezni lehessen ellene, amihez megfelelő vastagságú ólomra vagy vasbetonra van szükség. A belső sugárterhelésben a szerepe kicsi, ami a nagy áthatoló-képességből adódik, de a külső dózist szinte teljes egészében innen származtatjuk.

Neutronsugárzás: Olyan nagy energiájú termikus sugárzás, amely maghasadás során szabadul fel, erősen károsítja az emberi szervezetet, jelentős külső és belső sugárterhelést okozva. A neutronsugárzást hidrogénben gazdag anyaggal lehet elnyeletni.

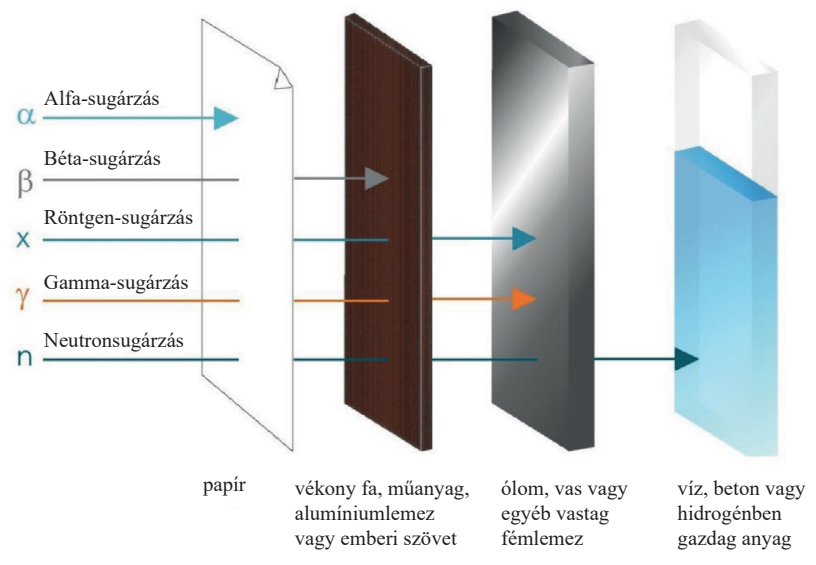

1. ábra. Sugárzások áthatoló-képessége

Forrás: www.mirion.com/learning-center/radiation-safety-basics/types-of-ionizing-radiation (A letöltés dátuma: 2017. 03. 20.) alapján szerkesztette a szerző

Az ionizáló sugárzás következtében érvényesülő biológiai hatásokat két csoportba soroljuk. Ezek a sztochasztikus és determinisztikus hatások. A determinisztikus hatások jellemzője, hogy egy bizonyos dózisszint felett biztosan bekövetkeznek, súlyosságuk az elnyelt dózis nagyságától függ. A tünetek a dózis függvényében változhatnak időben és súlyosságban, az enyhe lefolyásútól a halálosig. A sztochasztikus hatás jellemzője, hogy nincs küszöbdózisa, de az általa okozott 
biológiai elváltozás valószínűsége a dózis mértékével egyenes arányban nő. Az elváltozások hónapokkal, akár évekkel később is okoznak rosszindulatú daganatos megbetegedéseket és genetikai mutációkat. $^{7}$

\section{Veszélyhelyzeti tervezési kategóriák}

A nukleáris veszélyhelyzetek kockázatainak mértékét és időbeli változásait figyelembe véve a Nemzetközi Atomenergia Ügynökség a nukleáris létesítményeket és radioaktív anyagokkal tevékenységet végző intézményeket baleset-elhárítási szempontok alapján különböző tervezési kategóriába sorolja. ${ }^{8}$

I. veszélyhelyzeti tervezési kategória: A telephelyen, akár kis valószínüséggel is bekövetkező súlyos determinisztikus hatások léphetnek fel, amelyeknek a hatásai túlnyúlnak a telephely területén és veszélyeztetik a lakosságot. Jellemzően a 100 MWth feletti hőteljesítményű atomreaktorokat, fütőelem pihentető medencéket és olyan speciális radioaktív anyagokkal foglalkozó telephelyeket sorolunk ide, amelyeknél a kiszóródás következtében determinisztikus hatások lépnek fel az üzem területén kívül.

II. veszélyhelyzeti tervezési kategória: Akkor sorolandó ide egy telephely, ha egy ott bekövetkező esemény sürgős óvintézkedéseket tesz szükségessé a környező lakosság körében, de az üzemi területen kívül nem lép fel determinisztikus hatás. Ide tartoznak a 2-100 MWth közötti atomreaktorok, az aktív hütést igénylő fütőelem-tárolók, vagy ha a telephely közvetlen körzetében ellenőrizetlen kritikusság léphet fel és a baleset folyamán diszperz radioaktív anyagok kerülhetnek ki.

III. veszélyhelyzeti tervezési kategória: Abban az esetben soroljuk ide a telephelyet, ha a sürgős óvintézkedéseket indokolttá tevő esemény azon belülre korlátozódik. Ebbe a kategóriába a 2 MWth-nál nem nagyobb hőteljesítményü atomreaktorok, az 1 méteres távolságon belül $100 \mathrm{mGy/h}$ dózisteljesítményü árnyékolatlan sugárforrások tartoznak, vagy a telephelyen belül súlyos óvintézkedések bevezetését szükségessé tevő diszperzzé váló radioaktív kiszóródás léphet fel.

IV. veszélyhelyzeti tervezési kategória: Ebbe a kategóriába elsősorban a radiológiai veszélyhelyzetet előidéző tevékenységek sorolhatók, amelyek előre nem látható kiterjedésű területeken teszik szükségessé a sürgősségi óvintézkedések bevezetését. Ide tartoznak az illegális tevékenységek, a szállítási és mobil sugárforrással kapcsolatos feladatok végrehajtása vagy az ipari radiográfiás sugárforrások és radiotermikus generátorok. Bár az e kategóriába sorolt tevékenységek kisebb veszélyt jelentenek, de jellegük miatt az ország bármely területén előfordulhatnak, ezért az ilyen jellegű fenyegetettségre minden közigazgatási területnek fel kell készülni. A tevékenységi kategóriát további veszélyhelyzettípusokra kell bontani:

a) sugárforrással előidézett veszélyhelyzetek;

b) szállítási balesetek;

1996. évi CXVI. törvény.

BogNÁr et al. 2013. 
c) súlyos besugárzás;

d) szándékosan előidézett veszélyhelyzet (terrortevékenység).

V. veszélyhelyzeti tervezési kategória: A más országok I. és II. tervezési kategóriájába sorolt létesítményeinek balesetei, valamint a nukleáris és radioaktív balesetek során reálisan valószínűsíthető magyarországi élelmiszerek korlátozását szükségessé tevő események tartoznak ide.

1. táblázat. Magyarországot veszélyeztető létesítmények és tevékenységek besorolása

\begin{tabular}{|l|l|}
\hline Paksi Atomerömü & I. kategória \\
\hline A Kiégett Kazetták Átmeneti Tárolója (KKÁT) II. kategória \\
\hline Budapesti Kutatóreaktor \\
\hline Izotópintézet Kft. \\
\hline Budapesti Müszaki és Gazdaságtudományi Egyetem Oktatóreaktor \\
\hline Püspökszilágyi Radioaktív Hulladék Feldolgozó és Tároló Telep \\
\hline (RHFT) Nemzeti Radioaktív Hulladéktároló, Bátaapáti \\
\hline Bohunice Atomerőmü \\
\hline Mohovce Atomerőmü \\
\hline Krsko Atomerőmü \\
\hline Dukovany Atomerőmű \\
\hline Temelin Atomerőmü \\
\hline
\end{tabular}

Forrás: BOGNÁR et al. 2013, 517.

\section{Nukleáris veszélyhelyzeti osztályok}

A nukleáris veszélyhelyzetek során szükséges hatékony beavatkozások érdekében olyan veszélyhelyzetosztályi besorolás lett kialakítva, amely tartalmazza a szükséges műveletek végrehajtását az elhárítás és következmény enyhítése érdekében, valamint az esemény súlyosságának tükrében a dolgozók megfelelő védelmét és a sürgős lakossági óvintézkedések elrendelését. Az osztályba sorolt beavatkozások hatékonyságának érdekében az intézkedéseket késedelem nélkül meg kell kezdeni és a továbbiakban folyamatos koordinációt tesz szükségessé. ${ }^{9}$

Veszélyhelyzeti osztályok:

- Általános veszélyhelyzet: Nagy kiterjedésű területen teszi indokolttá a sürgős óvintézkedések azonnali bevezetését, a sugárterhelés mértéke és a radioaktív anyag környezetbe jutása miatt, vagy mivel annak nagyfokú kockázata lép fel. 
- Helyi veszélyhelyzet: A környezetben tartózkodók sugárterhelése az események következtében nagymértékben megnövekedhet, ezért azonnali intézkedéseket kell végrehajtani a következmények mérséklése érdekében és elő kell készíteni a lakosságvédelmi óvintézkedéseket.

- Létesítményi veszélyhelyzet: A nukleáris vagy radioaktív anyagot alkalmazó létesítmény tevékenysége során a védelem nagymértékü csökkenése következhet be, amely az üzem területére korlátozódik. Az események folyamán azonnali védelmi intézkedéseket kell végrehajtani a telephely személyzete érdekében és a következmények mérséklésére.

- Potenciális veszélyhelyzet: A körzetben tartózkodók védelmi szintjének jelentős csökkenése vagy abban bekövetkezett bizonytalan változások esetén alkalmazott osztály, amelynél azonnali kockázat- és következményfelmérésre van szükség annak szakszerü mérséklése érdekében.

Az I. és II. tervezési kategóriába sorolt létesítmények esetében mind a négy veszélyhelyzeti osztályt figyelembe kell venni, míg a III. tervezési kategóriánál, annak létesítményen belüli jellege miatt csak a létesítményi veszélyhelyzet és a potenciális veszélyhelyzet jöhet relevánsan számításba. A IV. tervezési kategória nem létesítményhez kötött, ezért a létesítményi veszélyhelyzet ennél a kategóriánál nem értelmezhető, azonban a sürgős óvintézkedések megállapítása specifikusan lehetséges. Az V. tervezési kategóriába sorolt létesítmények esetében élelmiszeróvintézkedési protokollokat kell bevezetni abban az esetben, ha a külföldön I. és II. tervezési kategóriába sorolt létesítmény általános veszélyhelyzete lép életbe.

Magyarországi veszélyhelyzetek csoportosítása a létesítmények és tevékenységük tükrében:

2. táblázat. Veszélyhelyzeti osztályok a tevékenységekhez viszonyítva

\begin{tabular}{|c|c|}
\hline $\begin{array}{c}\text { Veszélyhelyzeti osztály } \\
\text { Általános veszélyhelyzet }\end{array}$ & $\begin{array}{c}\text { Létesitmény, tevékenység } \\
\text { Paksi Atomerőmü }\end{array}$ \\
\hline Helyi veszélyhelyzet & $\begin{array}{r}\text { Paksi Atomerömü, Kiégett Kazetták Átmeneti Tárolója, Budapesti Kutatóreaktor, } \\
\text { Izotópintézet Kft.; radioaktív anyagokkal végzett tevékenységek }\end{array}$ \\
\hline Létesítményi veszélyhelyzet & $\begin{array}{r}\text { Paksi Atomerőmü, Kiégett Kazetták Átmeneti Tárolója, Budapesti Kutatóreaktor, } \\
\text { Izotópintézet Kft., Budapesti Műszaki és Gazdaságtudományi Egyetem Oktatóreaktor; } \\
\text { nagy aktivitású radioaktív anyagokat alkalmazó létesítmények }\end{array}$ \\
\hline Potenciális veszélyhelyzet & $\begin{array}{r}\text { Paksi Atomerőmü, Kiégett Kazetták Átmeneti Tárolója, Budapesti Kutatóreaktor, } \\
\text { Izotópintézet Kft., Budapesti Müszaki és Gazdaságtudományi Egyetem Oktatóreaktor; } \\
\text { nagy aktivitású radioaktiv anyagokkal végzett tevékenységek }\end{array}$ \\
\hline
\end{tabular}

Forrás: BOGNÁR et al. 2013, 519

\section{Potenciális károsító hatások}

A nukleáris veszélyhelyzetek kapcsán mindenképpen részletezni kell a fellépő károsító hatásokat. Az ionizáló sugárzás hatásain túl felléphetnek egyéb egészségkárosító hatások, amik nem a sugárzáshoz köthetők. Nem beszélve az esemény által a környezetre és a gazdaságra 
gyakorolt hatásokról. A hatások bekövetkezési szempontból eltérőek lehetnek, de általánosan elmondható, hogy egy időben jelentkeznek, de hatóidejük specifikusan különböző továbbá, nem törvényszerü, hogy minden hatás érvényesül egyidejüleg, ugyanakkor egymás katalizátorai is lehetnek. Egy veszélyhelyzeti esemény során fellépő komoly radiológiai következménynek például egészségügyi, környezeti és gazdasági vonzatai is vannak, nagyságrendjeinek pedig a kiterjedés nagysága lesz a mértéke. ${ }^{10}$

3. táblázat. Veszélyhelyzeti, potenciális károsító hatások

\begin{tabular}{|c|c|c|c|}
\hline Veszélyhelyzeti osztály & Létesítmény, tevékenység & Következmények & Kiterjedés \\
\hline Általános veszélyhelyzet & Paksi Atomerőmü & $\begin{array}{l}\text { determinisztikus; } \\
\text { sztochasztikus; } \\
\text { nem-radiológiai; } \\
\text { gazdasági; } \\
\text { környezeti }\end{array}$ & $\begin{array}{c}\text { általánosan nagy kiterjedés; } \\
\text { több 10-100 km }\end{array}$ \\
\hline Helyi veszélyhelyzet & $\begin{array}{l}\text { Paksi Atomerőmű, Kiégett Kazetták } \\
\text { Átmeneti Tárolója, Budapesti Kutató- } \\
\text { reaktor, Izotópintézet Kft.; radioaktív } \\
\text { anyagokkal végzett tevékenységek }\end{array}$ & $\begin{array}{l}\text { determinisztikus; } \\
\text { sztochasztikus; } \\
\text { nem-radiológiai; } \\
\text { gazdasági; } \\
\text { környezeti }\end{array}$ & $\begin{array}{c}\text { telephely; } \\
\text { telephelyen kívül néhány } \\
100 \text { m - néhány km }\end{array}$ \\
\hline $\begin{array}{l}\text { Létesítményi } \\
\text { veszélyhelyzet }\end{array}$ & $\begin{array}{c}\text { Paksi Atomerőmű, Kiégett Kazetták } \\
\text { Átmeneti Tárolója, Budapesti Kutató- } \\
\text { reaktor, Izotópintézet Kft., Budapesti } \\
\text { Műszaki és Gazdaságtudományi } \\
\text { Egyetem Oktatóreaktor; } \\
\text { nagy aktivitású radioaktív anyagokat } \\
\text { alkalmazó létesítmények }\end{array}$ & $\begin{array}{l}\text { determinisztikus; } \\
\text { sztochasztikus; } \\
\text { nem-radiológiai; } \\
\text { gazdasági }\end{array}$ & létesítményen belüli \\
\hline $\begin{array}{c}\text { Potenciális veszély- } \\
\text { helyzet }\end{array}$ & $\begin{array}{l}\text { Paksi Atomerőmü, Kiégett Kazetták } \\
\text { Átmeneti Tárolója, Budapesti Kutató- } \\
\text { reaktor, Izotópintézet Kft., Budapesti } \\
\text { Műszaki és Gazdaságtudományi } \\
\text { Egyetem Oktatóreaktor; } \\
\text { nagy aktivitású radioaktív anyagokkal } \\
\text { végzett tevékenységek }\end{array}$ & $\begin{array}{l}\text { nem-radiológiai; } \\
\text { gazdasági }\end{array}$ & $\begin{array}{l}\text { létesítményen belüli; } \\
\text { a tevékenység szük körze- } \\
\text { tében }\end{array}$ \\
\hline
\end{tabular}

Forrás: BoGNÁR et al. 2013, 520.

\section{Veszélyhelyzeti óvintézkedések}

Az adott létesítmény üzemeltetése által ellenőrzött és körülvett biztonsági terület minősül az üzem telephelyének. Abban az esetben, ha szállítás közben vagy ellenőrizetlen területen következik be a veszélyhelyzet, annak nincs kontrollált területe vagy telephelye, ezért a környezeti tényezőket és a sugárforrás tulajdonságait figyelembe véve ki kell jelölni a biztonsági területet. I. és II. veszélyhelyzeti tervezési kategóriába sorolt létesítmények esetében bekövetkezett

10 ÁVIT 2016, II. modul; BogNÁR et al. 2013, 517. 
jelentős veszélyhelyzetkor a biztonsági beavatkozások tervezése a kiindulópont és a létesítménytől való távolság függvényében változik. ${ }^{11}$

- Megelőző óvintézkedések zónája (MÓZ): Azáltalános veszélyhelyzet megállapítását követően azonnal elrendelt végrehatási intézkedések, amelyeket az I. tervezési kategóriába sorolt létesítmények esetében az elöre kijelölt körzeten belül vezettek be. A sürgős intézkedések elöre megtervezettek a sugárforrás és a potenciálisan kialakuló veszélyhelyzeti esemény függvényében. Ezek olyan óvintézkedések, amelyek célja a súlyos determinisztikus hatások megelőzése és a sztochasztikus hatások kialakulásának minimalizálása közvetlenül a kibocsátás következtében vagy röviddel azt követően.

- Sürgős óvintézkedések zónája (SÓZ): Az I. és II. tervezési kategóriába sorolt létesítmények esetében a tervezett sürgős óvintézkedéseket végrehajtó intézkedések, az előzetesen meghatározott területen. A környezetmonitorozás és üzemállapot függvényében olyan azonnali intézkedések végrehajtásáról van szó, amelyek a lakosság és a környezet sugárterhelés-védelme érdekében kell, hogy megvalósuljanak, és ezáltal a jogszabályokban meghatározott dózisokat ne érje el a kibocsátás mértéke.

- Élelmiszer-fogyasztási korlátozások óvintézkedési zónája (ÉÓz): A veszélyhelyzet kiterjedésétől és mélységétől függően előfordulhat, hogy szükségessé válik egy adott területen belül a lakosság élelmiszer-fogyasztásának korlátozása, a mezőgazdasági termelések és élelmiszer-feldolgozó üzemek tevékenységének szükség szerinti szigorú szabályozása vagy korlátozása. Ennek célja az érintett területeken termelt élelmiszerek fogyasztása általi inkorporáció elkerülése. A zóna kiterjedése több száz kilométeres területet jelenthet, ami a lakosság áttelepítését is vonhatja maga után.

A III. és IV. tervezési kategóriába sorolt létesítmények esetében általában nem szükséges a megelőző és sürgős óvintézkedések zónájának kijelölése. A MÓZ és SÓZ területek általában olyan természetes határokkal (például utak, folyók, hegyvonulatok) vannak körvonalazva, amelyek az operatív intézkedések alatt egyértelmüen beazonosíthatók. Az óvintézkedési zónák mérete függ a kibocsátás mértékétől és a potenciális következmények elemzésének eredményétől, valamint a károsító hatások az egyes óvintézkedési zónákban specifikáltan változhatnak.

\section{Az egyes zónák kiterjedésének mértéke}

A nukleáris veszélyhelyzet óvintézkedési zónái az egyes létesítmények hatásainak területi kiterjedésétől függően változnak. Az V. tervezési kategóriába sorolt létesítmények esetében például ugyan külföldi, I. és II. tervezési kategóriába sorolt létesítményröl beszélünk, mégis annak nukleáris veszélyhelyzete élelmiszer-korlátozást eredményezhet hazai területeken. A IV. veszélyhelyzeti tervezési kategóriába sorolt tevékenységek esetében nehéz konkrét kiterjedést meghatározni, hiszen annak paraméterei előre nem meghatározhatóak, csak potenciális helyzetvariációk modellezhetők le. ${ }^{12}$

11 ÁVIT 2016, II. modul; 2011. évi CXXVIII. törvény.

12 BognÁr et al. 2013; 487/2015. Korm. rendelet; Atomerőmü Tüzoltóság 2013. 
4. táblázat. Veszélyhelyzeti zónahatárok a tervezési kategóriába sorolt létesítményeknél

\begin{tabular}{|c|c|c|c|}
\hline & MÓz & SÓz & ÉÓZ \\
\hline \multicolumn{4}{|l|}{ I. VTK } \\
\hline Paksi Atomerőmü & $3 \mathrm{~km}$ & $30 \mathrm{~km}$ & $300 \mathrm{~km}$ \\
\hline \multicolumn{4}{|l|}{ II. VTK } \\
\hline KKÁT & - & - & $3 \mathrm{~km}$ \\
\hline Budapesti Kutatóreaktor & - & KFKI telephely & $1 \mathrm{~km}$ \\
\hline Izotópintézet Kft. & - & KFKI telephely & $1 \mathrm{~km}$ \\
\hline \multicolumn{4}{|l|}{ III. VTK } \\
\hline BME Oktatóreaktor & - & - & - \\
\hline $\begin{array}{l}\text { Radioaktív Hulladék Feldolgozó és Tároló Telep, } \\
\text { Püspökszilágyi }\end{array}$ & - & - & $3 \mathrm{~km}$ \\
\hline Nemzeti Radioaktív Hulladéktároló, Bátaapáti & - & - & $3 \mathrm{~km}$ \\
\hline \multicolumn{4}{|l|}{ V. VTK } \\
\hline Bohunice & $3 \mathrm{~km}$ & $30 \mathrm{~km}$ & $300 \mathrm{~km}$ \\
\hline Mohovce & $3 \mathrm{~km}$ & $30 \mathrm{~km}$ & $300 \mathrm{~km}$ \\
\hline Krsko & $3 \mathrm{~km}$ & $30 \mathrm{~km}$ & $300 \mathrm{~km}$ \\
\hline Dukovany & $3 \mathrm{~km}$ & $30 \mathrm{~km}$ & $300 \mathrm{~km}$ \\
\hline Temelin & $3 \mathrm{~km}$ & $30 \mathrm{~km}$ & $300 \mathrm{~km}$ \\
\hline
\end{tabular}

A fenti táblázatból egyértelműen látszik, hogy a tervezési kategóriák függvényében előre meghatározottak az óvintézkedési zónák. A hazánkhoz legközelebb eső atomerőművek megelőző és sürgős óvintézkedési zónái kívül esnek Magyarország területén, azonban az Élelmiszerfogyasztási korlátozások óvintézkedési zónája eléri Magyarországot. Magyarországi tekintetben a „Megelőző óvintézkedések zónája” csak a Paksi Atomerőmű körül van kijelölve. Ennek következménye, hogy általános veszélyhelyzet kihirdetése során az operatív intézkedéseket azonnal végre kell hajtani, és a területen lévőket haladéktalanul kimenekíteni, hogy a sztochasztikus és determinisztikus hatások megelőzhetők legyenek. Ugyancsak a Paksi Atomerőmű vonatkozásában van kijelölve a „Sürgős óvintézkedések zónája” Magyarországon 30 kilométeres körzetben, illetve kisebb léptékben a Budapesti Kutatóreaktort magába foglaló Központi Fizikai Kutatóintézet (KFKI) telephelyén. Ezeken a helyeken a nukleáris veszélyhelyzet során olyan intézkedéseket kell végrehajtani, mint például elzárkóztatás, jódprofilaxis és kimenekítés. Ahogy a külföldi atomerőművek nukleáris veszélyhelyzet általi élelmiszer-fogyasztási korlátozások óvintézkedési zónájába beletartozik hazánk területe, úgy a magyar nukleáris létesítmények esetében is kihatással van erre a területre az üzem típusának függvényében a korlátozási zóna. A Paksi Atomerőmű által kiváltott veszélyhelyzet során az élelmiszer-korlátozás gyakorlatilag lefedi Magyarország teljes területét, ezért ebben az esetben olyan hosszú távú óvintézkedések bevezetésére van szükség, amelyek révén a lakosság elkerüli az inkorporációt, ugyanakkor a fellépő gazdasági és környezeti válság révén nem vezet társadalmi összeomláshoz. A szabályozások és korlátozások a sugármonitorozási és tervezett védelmi-elhárítási intézkedéseknek megfelelően lépnek életbe. ${ }^{13}$

13 Atomerőmü Túzoltóság 2012. 


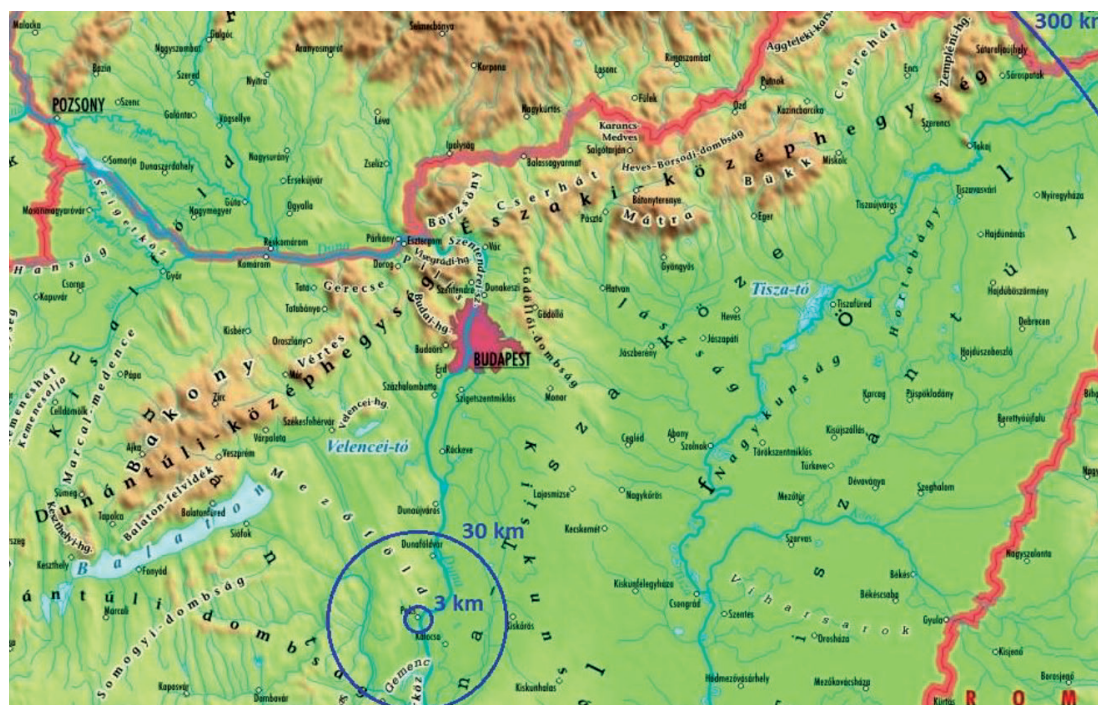

2. ábra. A Paksi Atomerömű veszélyhelyzeti zónahatárai ${ }^{14}$

Forrás: www.map.hu/Attekinto/Magyarorszag/Magyarorszag_domborzata (A letöltés dátuma: 2019. 01. 20.) alapján szerkesztette a szerzô

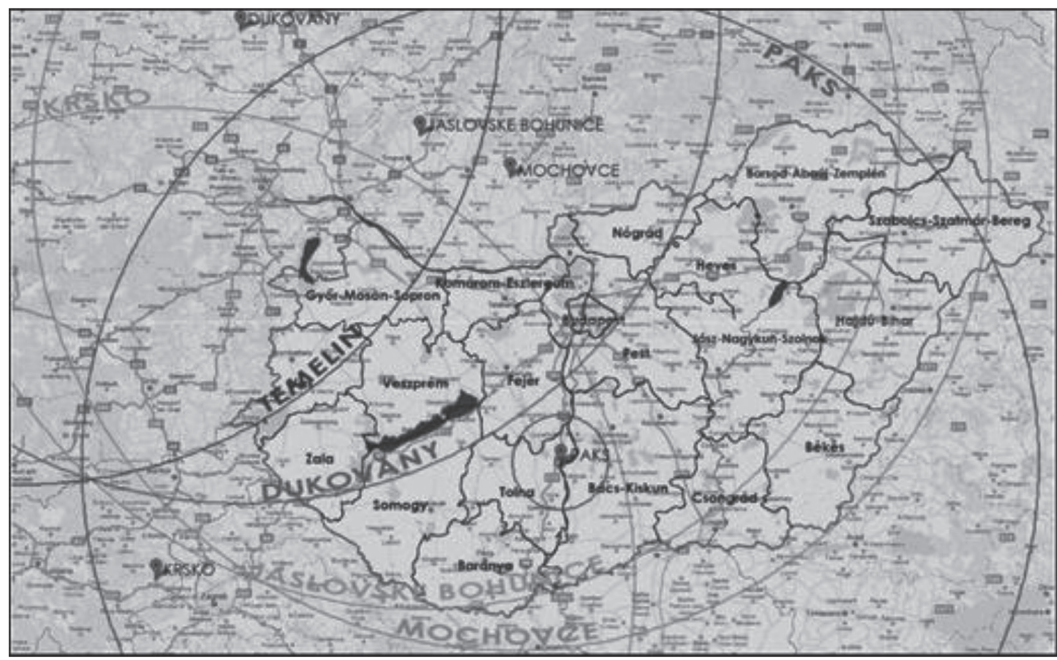

3. ábra. Veszélyhelyzeti zónahatárok a tervezési kategóriába sorolt létesítményeknél

Forrás: BOGNÁR et al. 2013, 526.

14 Magyarország átszerkesztett domborzati térképe, a Google Maps távolságmérỏjével meghatározott távokkal. 


\section{Nukleáris baleset-elhárítási feladatok}

\section{Országos Nukleárisbaleset-elhárítási rendszer}

Magyarországon, a lakosság védelme érdekében, a veszélyhelyzet elhárítására vagy a következmények enyhítésére irányuló intézkedések végrehajtása céljából Országos Nukleárisbalesetelhárítási rendszer (továbbiakban: ONER) müködik. Az ONER feladata az események elhárítására való felkészülés és annak kivitelezése a központi, ágazati, területi és helyi szintű szervezeteit felhasználva. A lakosság rendkívüli, nem tervezett sugárterhelését előidéző események kapcsán a biztonság érdekében átfogó intézkedéseket vezet be, amelyekkel az elhárítás sikerességét és a következmények csökkentését szavatolja. Ezek összehangolása kormányszintű feladat, amelyet a katasztrófavédelemről és a hozzá kapcsolódó egyes törvények módosításáról szóló 2011. évi CXXVIII. törvény, valamint az annak végrehajtásáról szóló 234/2011. (XI. 10.) Korm. rendelet szabályoz. Ezen jogszabályokhoz kapcsolódik az ONER felépítéséröl és feladatairól rendelkező 167/2010. (V. 11.) Korm. rendelet.

Az ONER müködését és irányítását a katasztrófavédelemmel összefüggő döntések előkészítésére és a védekezéssel kapcsolatos feladatok ágazati összehangolására felállított kormányzati szerv, a Katasztrófavédelmi Koordinációs Kormánybizottság (továbbiakban: KKB) látja el. Az ONER müködését tekintve négy müködési állapotba sorolva végzi a feladatát, azoknak megfelelő szinten és minőségben:

- normál működési állapot;

- készenléti működési állapot;

- veszélyhelyzeti múködési állapot;

- helyreállítási működési állapot.

\section{A KKB feladatai}

A KKB állapítja meg az ONER müködési rendjét, amelyet a központi veszélyelhárítási terv részeként az Országos Nukleárisbaleset-elhárítási Intézkedési Tervben rögzít. A normál müködési állapotban a nukleáris létesítmények veszélyhelyzeti felkészültségének nyomon követésével foglalkozik, hogy a felkészülési és a következményelhárítási eljárások megfelelően lefedjék a nukleáris létesítmények veszélyhelyzet-kezelési képességeit, amiről kétévente az Országos Atomenergia Hivatallal (továbbiakban: $\mathrm{OAH}$ ) együttmüködve az atomenergia alkalmazója tájékoztatóanyagot készít. A KKB háromévente nukleáris balesetelhárítási műszaki fejlesztési javaslatot készít, évenkénti bontású költségvetési tervvel, igazodva a fö fejlesztési területekhez. Az ONER működésével kapcsolatosan felkészültségi vizsgálatot tart, továbbá képzési és gyakorlatozási tevékenységgel kapcsolatos javaslatokat tesz. Készenléti és Veszélyhelyzeti működési állapotokban a felmerülő kérdések elemzésével, a problémák tudományos megválaszolásával és a kormányzati döntés-előkészítéssel kapcsolatos szakmai feladatokat látja el. A helyreállítási működési állapotban a KKB feladata a nukleáris balesetek okainak feltárása és kivizsgálása. ${ }^{15}$

15 2011. évi CXXVIII. törvény. 
Normál müködési állapot

Ebben az állapotban az országos sugárzási szint folyamatos monitorozása és a radiológiai adatok gyüjtése a feladat a riasztási rendszerhez igazítva. Az adatokat elemzik, értékelik és ellenőrzik. Naprakészen tartják a Nukleárisbaleset-elhárítási Intézkedési Terveket, és az abban foglaltakat az érintett szervezetekkel gyakoroltatják, valamint biztosítják az anyagi-technikai feltételek meglétét, a lehetséges elhárítási feladatok megvalósításához.

Készenléti működési állapot

A veszélyhelyzeti müködési állapotot el nem érő, de sugárvédelmi tevékenységet és lakossági tájékoztatást igénylő feladatokat foglal magában a normál működési állapot feladatain felül. Ebben az állapotban radioaktív kibocsátás közvetlen veszélyével kell számolni valamely hazai vagy országhatártól 300 km-en belül fekvő nukleáris, illetve sugárzó anyagot felhasználó és tároló létesítményben. Ez az állapot lép életbe akkor is, ha az OSJER mérőállomásain a meghatározott szinthez tartozó riasztási jelzés érkezik vagy olyan káresemény bekövetkezésekor, ami a környezeti sugárterhelés növekedésével fenyeget. Ide tartoznak a Magyarország területén esetlegesen lezuhanó sugárveszélyes ürobjektumok is.

Veszélyhelyzeti működési állapot

Ebben az állapotban már konkrét lakosságvédelmi óvintézkedések bevezetésére van szükség, mivel a lakosság nem tervezett sugárterhelését előidéző esemény kockázatait és hatásait csökkenteni kell.

Helyreállítási működési állapot

A helyreállítás során biztosítani kell a normál müködési állapotra történő visszaállást. Minden olyan tevékenységet és intézkedést, amely ehhez a célhoz vezet vissza a helyreálítás részének kell tekinteni.

\section{Országos Sugárfigyelö, Jelző és Ellenőrző Rendszer}

A lakosság biztonsága érdekében folyamatosan működő automatikus sugárzásmérő állomásokat helyeztek ki, amelyek biztosítják a KKB döntés-előkészítő és döntéshozó tevékenységéhez a szükséges információkat. Ez az Országos Sugárfigyelő, Jelző és Ellenőrző Rendszer (továbbiakban: OSJER), amely működésének és szakmai munkájának irányítását a katasztrófák elleni védekezésért felelős miniszter végzi. AZ OSJER müködéséről a 167/2010. (V. 11.) Korm. rendelet határoz. ${ }^{16}$

16 BogNÁR et al. 2013; 2011. évi CXXVIII. törvény; 167/2010. Korm. rendelet. 


\section{Az OSJER feladatai}

Az országos sugárzási helyzet monitorozásával megalapozza az ONER müködési állapotainak megfelelö riasztását és értesítési rendszerét, valamint a müködési állapot függvényében a közreműködő szervek tájékoztatását, amelyet az atomenergia alkalmazójánál működő mérőhelyek mérési adatai, illetve a katasztrófavédelmi központi szerv Nukleáris Baleseti Információs és Értékelő Központjának (továbbiakban: NBIÉK) nyomon követett értékeléseire alapozza. A távmérő hálózaton keresztül érkező figyelmeztetés vagy riasztás esetén hitelességvizsgálatot végez az esetleges kiváltó okok meghatározásával és esemény állapotjelentést készít az ONER-t működtető szervek vezetőinek.

Az NBIÉK az országos korai előrejelzés központi feladataival, a nemzetközi radiológiai adatcsere rendszerével és a lakosság nukleáris baleset-elhárítással kapcsolatos tájékoztatásával foglalkozik, a lehetséges terjedési útvonalak elörejelzésével, valamint a KKB online, valós idejü döntés-elökészítő tevékenységének müködtetésében is részt vesz.

\section{Nukleárisbaleset-elhárítási döntéstámogató rendszer}

Egy kialakult nukleáris veszélyhelyzetben a döntéstámogató rendszerek nagymértékủ segítséget tudnak nyújtani az egyes szituációk pontos felméréséhez, értékeléséhez, amely elengedhetetlen a hatékony operatív beavatkozás tekintetében. A feladatok sokrétűsége miatt nem egyszemélyi felelőse van a kialakult veszélyhelyzet kezelésének, ugyanakkor a meglévő információk segítségével a szükséges intézkedések bevezetésében jelentős segítséget nyújthat. Nagy jelentősége van továbbá a normál és veszélyhelyzeti időszakokban a hiteles tájékoztatásban és a folyamatos sugárzási helyzetértékelésben. Ilyen a BM Országos Katasztrófavédelmi Főigazgatóság által az NBIÉK-ben üzemeltetett RODOS-rendszer. A Realtime, Online, Decision SuppOrt System teljes elnevezésből származó angol mozaikszó. A rendszer olyan valós idejű, online nemzetközi döntéstámogató rendszer, amely az Európai Unió támogatásával lett kifejlesztve, abban a szellemben, hogy a rendszert használó országok nukleárisbaleset-elhárítása során a regionális együttmüködés mellett pontos, akár határon túli terjedések megjelenítésével hatékony és egységes kárelhárítási és veszélyhelyzet-kezelési együttműködést tegyen lehetővé. A rendszer bármely európai ország területén keletkezett baleset modellezésével képes hatáselemzést készíteni, hogy a javasolt óvintézkedések függvényében csökkentse a károsító hatásokat és könnyítse a szükséges döntések meghozatalát azok priorizált sorrendjében. A rendszer négy szinten müködik, amelyek az alkalmazott óvintézkedésekhez viszonyítva lettek kialakítva:

- 0 . szint: Közvetlenül mért vagy származtatott radiológiai adatok begyüjtése, elemzése és megjelenítése.

- 1. szint: A radiológiai helyzet térbeli és időbeli megjelenítése és annak elemzése a várható események elörejelzésével;

- 2. szint: Beavatkozási szimulációk futtatása az elemzések értelmezésével;

- 3. szint: Prioritási sorrend felállítása az egyes alternatív óvintézkedési stratégiákhoz. 


\section{Nemzetközi radiológiai adatcsere rendszer (EURDEP)}

Világszerte kiépítették azokat a sugárfigyelő és jelző rendszereket, amelyek az ionizálós sugárzás terjedését hivatottak figyelmeztetni. Ezek a helyhez kötött sugármérő állomások folyamatosan továbbítják az adatokat, hogy a határokon átnyúló, következményekkel járó esetleges balesetek hatékonyabb kezelését elősegítsék számos ország nemzetközi adatcsererendszerében történő egyesítésével. Ilyen rendszer az Európai Radiológiai Adatcsere Platform (továbbiakban: EURDEP). A rendszer működéséhez minden európai uniós tagország kötelező jellegü adatszolgáltatást nyújt, de az unión kívüli országok csatlakozása is megengedett. A rendszerhez alapvetően minden ország napi rendszerességű adatot szolgáltat, de veszélyhelyzetben ez minimum kétóránkénti gyakoriságúra módosul. Az általános eljárás azonban manapság az, hogy a mérési eredmények minden helyzetben egyórás intervallumra szűkülnek. ${ }^{17}$

\section{Magyarország nukleárisbaleset-elhárítási összképe}

Az alaposan kidolgozott védelmi eljárások teszik lehetővé, hogy a nukleáris erőforrások felhasználása a lehető legoptimálisabb biztonság mellett valósulhasson meg. A nemzetközi ajánlások és tapasztalatok, valamint ezek fényében az ország sajátosságaira hangolt nukleárisbaleset-elhárítás hatékony müködése jelenti azt a védelmi bástyát, amely szervesen kapcsolódik a világ nukleáris energiabiztonságához. A magyarországi nukleárisbaleset-elhárítás nemcsak eleget tesz a jogszabályi kötelezettségeknek és a nemzetközi ajánlásoknak, de olyan preventív szervezési struktúrával és cselekvőképes operatív tervezéssel rendelkezik, amellyel az ország határain túlmutatóan is megállja a helyét egy esetlegesen kialakuló veszélyhelyzet kapcsán. A jelen cikkrészben bemutatott alapok a következő részben további kifejtésre kerülnek a paksi atomerőmű nukleárisbaleset-elhárítási rendszere kapcsán. Az atomerőmű biztonságfilozófiája szervesen kapcsolódik az országos védelmi tervezéshez, valamint a nemzetközi operatív beavatkozási eljárások honosításával és a helyi specifikumokra történt fejlesztésekkel teljes körü védelmet biztosít a nukleáris veszélyhelyzetekkel szemben.

\section{Felhasznált irodalom}

Atomerőmü Tủzoltóság (2012): Atomerömüves rendszerek. ATOMIX Kft. Tüzoltási és Kárelhárítási Szakágazat, Szakmai Ismeretek Oktatási anyag, ATOMIX at-me-6.2.2.-11-v2. 2012. 08. 01.

Atomerőmü Tủzoltóság (2013): Üzemzavar elháritási oktatási anyag. ATOMIX Kft. Tủzoltási és Kárelhárítási Szakágazat, Szakmai Ismeretek Oktatási anyag, ATOMIX at-me-6.2.2.-1-v2. 2013. 07. 01.

BereK Tamás (2010): Honvédelmi Ismeretek - ABV (CBRN) Védelmi Alapismeretek jegyzet. Budapest, Zrínyi Miklós Nemzetvédelmi Egyetem.

BOGNÁR Balázs - KÁTAI-URBÁN Lajos - KOSSA György - KozMA Sándor - SZAKÁL Béla - VASS Gyula (2013): Iparbiztonságtan l. - Kézikönyv az iparbiztonsági üzemeltetöi és hatósági feladatok ellátásához. Budapest, Nemzeti Közszolgálati Egyetem, Nemzeti Közszolgálati és Tankönyv Kiadó Zrt.

17 BOgNÁR et al. 2013 
MVM Paksi Atomerőmű Zrt., Átfogó Veszélyhelyzet-kezelési és Intézkedési Terv, I. modul: Általános kötet, Verziószám: 9.3, 2016. 02. 04.

MVM Paksi Atomerőmű Zrt., Átfogó Veszélyhelyzet-kezelési és Intézkedési Terv, II. modul: Nukleárisbaleset-elhárítási Intézkedési Terv, Verziószám: 9.3, 2016. 02. 04.

\section{Internetes források}

Magyarország domborzata. Elérhető: www.map.hu/Attekinto/Magyarorszag/Magyarorszag_domborzata (A letöltés dátuma: 2019. 09. 28.)

Types of ionizing radiation (2015). Elérhető: www.mirion.com/learning-center/radiation-safety-basics/ types-of-ionizing-radiation (A letöltés dátuma: 2019. 09. 28.)

\section{Jogforrások}

167/2010. (V. 11.) Korm. rendelet az Országos Nukleárisbaleset-elhárításról 1996. évi CXVI. törvény az atomenergiáról 2011. évi CXXVIII. törvény a katasztrófavédelemröl és a hozzá kapcsolódó egyes törvények módosításáról 487/2015. (XII. 30.) Korm. rendelet az ionizáló sugárzás elleni védelemről és a kapcsolódó engedélyezési, jelentési és ellenőrzési rendszerről 